\title{
СПЕЦИФІКА РЕЖИСЕРСЬКОЇ ТВОРЧОСТІ ВОЛОДИМИРА МОСКОВЧЕНКА В ДИНАМІЦІ РОЗВИТКУ ТЕАТРАЛЬНОЇ КУЛЬТУРИ ЛУГАНЩИНИ
}

\author{
Тетяна Нечаєнко ${ }^{1 a}$, Сергій Плуталов ${ }^{2 b}$, Альона Дорофєєва ${ }^{3 c}$ \\ ${ }^{1}$ спеціаліст, доцент; e-mail: nechaenko.t@gmail.com; ORCID: 0000-0002-8329-2517 \\ ${ }^{2}$ спеціаліст; e-mail: si.plutalovv@gmail.com; ORCID: 0000-0001-9155-5324 \\ ${ }^{3}$ магістр; e-mail: alena.dorofeeva@ukr.net; ORCID: 0000-0001-6488-3031

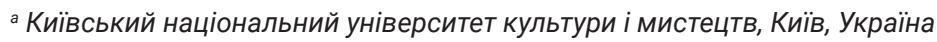 \\ ь Луганська державна академія культури і мистецтв, Київ, Україна \\ с Луганський обласний академічний український музично-драматичний театр, Київ, Україна
}

\section{Анотація}

Мета дослідження полягає в історико-аналітичному та мистецтвознавчому аналізі сучасних режисерських практик на сцені Луганського обласного академічного музично-драматичного театру на прикладі творчості одного з провідних його представників В. Московченка. Методологія дослідження базується на комплексному науковому підході та синтезі таких методів: історико-аналітичного - у дослідженні режисерського мистецтва В. Московченка в контексті театральної культури України в цілому; біографічного як засобу визначення етапів творчого становлення митця; теоретичного - для наукового узагальнення та систематизації фактологічного матеріалу. Наукова новизна дослідження полягає в тому, що вперше творчий шлях В. Московченка та його діяльність у Луганському обласному академічному музичнодраматичному театрі розглянуто як одну з вагомих сторінок українського театрального життя. Висновки. Кожна робота В. Московченка має свою театральну форму, свій хід режисерської думки, яка не тільки тісно пов'язана з першоджерелом, авторською п'єсою, а й надає йому інтерпретаційних ознак паралельного художнього світу, відтвореного в гармонії всіх складників театральної вистави. Саме це дає змогу говорити про наявність у майстра індивідуального стилю та мовної стилістики як системи, що впливає на сприйняття сценічних образів як самостійних режисерських персонажів, які проводять глядача через усі сценічні колізії, закладені режисерським задумом. На сцені Луганського обласного академічного українського музично-драматичного театру як духовного центру культурного життя регіону продемонстровано широку палітру театральних барв та режисерських знахідок у творчості В. Московченка, спрямованих на поєднання провідних тенденцій розвитку театрального мистецтва з досвідом корифеїв вітчизняної сцени.

Ключові слова: Луганський обласний академічний український музично-драматичний театр; театральна режисура XX століття; В. Московченко 


\section{Постановка проблеми}

У сучасному мистецтвознавстві недостатньо приділено уваги режисерським практикам регіонів, де працюють театральні лабораторії з оригінальним досвідом естетичного та художнього виховання. Проте накопичена кількість архівних матеріалів, які зберігаються у театральних закладах, рецензійний матеріал, присвячений яскравим подіям театрального життя в цих регіонах, доводить необхідність наукового аналізу та теоретичних узагальнень, які б розширили уявлення про варіативність підходів у тлумаченнях традицій національної спадщини.

\section{Аналіз останніх досліджень і публікацій}

Динаміка розвитку режисерського мистецтва обумовила появу численної кількості наукових праць і публіцистики, в яких досліджено, крім питань історії, теорії та практики театрального мистецтва (П. Саксаганський, Лесь Курбас, В. Василько, М. Терещенко, В. Неллі), авторські підходи до постановчих завдань режисерської діяльності (С. Данченко, М. Резнікович, Г. Товстоногов, Ю. Любимов, М. Захаров) щодо відродження театральних традицій у сучасних мистецьких практиках (А. Обертинська).

До джерельної бази дослідження ввійшли також статті, нариси, рецензії театральних критиків, інтерв'ю, що характеризують окремі здобутки сучасного режисерського досвіду, зокрема набутого в регіональних театральних установах. Їх аналіз дає змогу підсумувати досвід збереження національної театральної режисури у творчості її сучасних представників, зокрема В. Московченка.

Мета статті полягає в історико-аналітичному та мистецтвознавчому аналізі становлення театральної культури Луганщини в проєкції на сучасні режисерські практики Луганського музично-драматичного театру та творчості одного з провідних його представників В. Московченка.

\section{Виклад основного матеріалу}

Актуальність теми. Відродження засад української театральної культури потребує активізації уваги до аналізу питань, пов'язаних з подальшим розвитком сучасного режисерського мистецтва, з окресленням його типових рис не тільки з погляду ретроспекції історичного становлення, а й самих змін, що визначають трансформаційні тенденції, котрі простежуємо на рівні загальних універсальних ознак розвитку театральної творчості.

Актуальність теми зумовлена ще й підвищенням інтересу науковців до відродження та збереження ознак, притаманних національній сценічній культурі. Це особливо корелюється з діяльністю режисерів, які переважно репрезентують систему поглядів на соціокультурні цінності, відтворені в сучасних театральносинтезованих формах (О. Білецький, Р. Віктюк, С. Данченко, М. Резнікович).

Сучасні вітчизняні видання торкаються окремих питань історії, теорії та практики театрального мистецтва, підходів до постановочних завдань режисерської 
діяльності, підвищення рівня професійної режисерської майстерності; присвячені завданням становлення та відродження театральних традицій, аналізу певних режисерських і педагогічних надбань, особистому досвіду роботи. Проте мало уваги приділено режисерським практикам регіонів, де працюють театральні лабораторії з оригінальним досвідом естетичного та художнього результату. Усе це зумовило вибір теми: «Специфіка режисерської творчості Володимира Московченка в динаміці розвитку театральної культури Луганщини».

У творчому доробку В. Московченка понад сто вистав, яким притаманна яскрава театральна форма, поетичне, образне вирішення щодо сценічного простору. У своїх роботах режисер завжди майстерно відтворює світогляд людини сьогодення, випробовує нову естетику театральної мови, удається до використання сучасних засобів створення вистави. Завдяки більшості своїх робіт, серед яких «Безталання» і «Лиха іскра» І. Карпенка-Карого, «Антоній і Клеопатра» В. Шекспіра, «Сватання на Гончарівці» Г. Квітки-Основ'яненка, «Титарівна» за Т. Шевченком, «Свіччине весілля» І. Кочерги, В. Московченко став лауреатом таких всеукраїнських і міжнародних фестивалів, як «Театральний Донбас», «Прем'єри сезону», «Мельпомена Таврії». Та чи не найбільший успіх серед понад 100 вистав режисера випав на долю постановки «Ніч під Івана Купала» М. Старицького, яка принесла театру широке визнання на міжнародному рівні.

В. Московченку також належить розробка й постановка багатьох державних творчих акцій на Луганщині, серед яких і святкове театральне дійство, присвячене 60-річчю утворення Луганської області, і Міжнародний шевченківський фестиваль «В сім'ї вольній, новій», що відбувся у Луганську в 1998 році. В. Московченко - член журі Всеукраїнського огляду митців народної творчості, зокрема звітів міст і районів області, а також режисер-постановник усіх чотирьох звітів Луганщини в межах цього огляду.

Як доцент, викладач кафедри режисури та акторської майстерності Луганського державного інституту культури і мистецтв, В. Московченко протягом багатьох років регулярно поповнював трупу новою творчою енергією, запрошував до театру молодих спеціалістів, які вносили свіжий імпульс в життя колективу. На посаді художнього керівника він і зараз докладає багато зусиль для підвищення професійної майстерності тих акторів, яким відкрив шлях на сцену у своїх постановках, активно залучає молодь до роботи в нових творчих проєктах.

Отже, для України В. Московченко - один з театральних символів XXI століття, один з найталановитіших режисерів української сучасності, який привів Луганський український театр до справжнього творчого розквіту, шукаючи нову естетику театральної мови, сучасні засоби створення вистави. Таке порівняння - не випадковість. Шлях, який пройшла ця людина, пов'язаний з найяскравішими сторінками історії сучасного українського театру.

У контексті дослідження творчості В. Московченка варто згадати останні сторінки історії Луганського обласного академічного музично-драматичного театру. У 2014 році частину театру переміщено в Сєвєродонецьк. Майже рік театр, не маючи матеріальної бази, трупи, а певний час і керівництва, просто «значився на папері». У жовтні 2015 року до театру приходить новий керівник - молодий 
директор С. Дорофєєв, з появою якого театр ніби ковтнув свіжого повітря. Разом з новим директором до театру прийшли молоді актори та ті, які багато років віддали служінню Мельпомені саме в цьому Луганському театрі, а також на запрошення С. Дорофєєва до театру повертається В. Московченко. У лютому 2016 року він стає художнім керівником цього переміщеного театру.

Як зазначено вище, постановочний доробок В. Московченка становить понад сто вистав у різних театрах України. У переважній більшості зміст цих вистав засвідчує потужну енергетику національної літературної спадщини. Саме з нею пов'язаний колорит характерів у кожній його роботі, самобутність образного мислення та особливості авторського стилю.

Національний колорит, притаманний режисерським технологіям В. Московченка, вельми обумовлений творчими відносинами із сучасними українськими драматургами, зокрема Т. Іващенко, дружба з якою розпочалася у 2005 році, коли в Луганську відбулася перша постановка її п'єси «Таїна буття» на тему подружнього життя І. Франка.

Не менш важливою в житті режисера стала вистава за п'єсою Т. Іващенко «Втеча від реальності». Про інтерес до творчості драматурга з боку режисера свідчать також інші вистави - «Ідзанамі» та «Любов на замовлення». Театральний критик Алла Підлужна (2018) так описує свої враження:

«нтрига вистави «Любов на замовлення» тримає глядачів у напрузі відгадування: правда чи ні, любить чи обманює? Режисер і автор музичного оформлення Володимир Московченко дає "мітки" сучасних реалій. На відеоекрані-заднику, що стає головним елементом сценографічного рішення (художник Ірина Лубська), - кадри з сайтів знайомств, безліч жіночих облич, що чекають на зустріч з коханням. [...] Психологічні гойдалки щирості й брехні, наявності в людині світлої й темної сторін, режисером візуально вирішуються у вигляді шести кіл світла, в які персонажі потрапляють з темряви ігрового простору».

Наведений приклад режисерського читання п'єси дає змогу скласти загальне уявлення про те, якими є режисерські пріоритети в тлумаченні авторського тексту. Відповідь на питання, що є для В. Московченка професія режисера, він надає в інтерв'ю театрознавцю С. Максименко, в якому майстер згадує свій шлях до професії, що «до певної міри був випадковим, але водночас закономірним». Режисер описує його так:

«Я родом з театральної сім'ї: батько очолював Дніпропетровський театр імені Шевченка, Полтавський театр імені М. Гоголя, Харківський театр імені О. Пушкіна; мати викладала сценічну мову у Харківському інституті мистецтв. Отже, сімейна орієнтація, її театральні уподобання одразу визначили мій шлях. Оскільки я був дитиною начитаною, освіченою, спочатку хотів вступити на театрознавче відділення. Але того року не було набору, тому пішов на режисуру. Сподобалось!» (Московченко, 2006, с. 75)

Далі В. Московченко стверджував, що для нього «режисура - це обов'язкове поєднання широкого культурного обсягу». Водночас щиро режисера турбує ситуація, 
Вісник Київського національного університету культури і мистецтв. Серія: Сценічне мистецтво

що на тлі браку театральної культури серед деяких колег по цеху «можна побачити завзятих, емоційних, вольових режисерів, які пробивають собі шлях, розуміючи, що ця спеціяльність дає певні можливості реалізації: особистої і матеріяльної (більші, ніж в акторстві)». Такі «режисери-варяги» займають дуже привабливу позицію, здійснюючи постановки в різних театрах, але не пов'язують свою діяльність обов'язком виховання трупи. Проте, на думку В. Московченка, в Україні $є$ плеяда митців, хоч і невелика, «які працюють у конкретному місті, роблять чітко означену роботу в одному колективі. [...] До них належить Анатолій Канцедайло, режисер Дніпропетровського театру імені Тараса Шевченка. Він виховує свій колектив, має свою чітко визначену репертуарну політику, має свого глядача». Водночас, посилаючись на досвід діяльності Олександра Барсегяна у Харківському державному академічному російському драматичному театрі імені О. С. Пушкіна, який за останні десять років не запросив до співпраці жодного режисера, В. Московченко застерігає, що театрам важливо дотримуватися в репертуарі балансу між постановками запрошених і штатних режисерів. У своїй діяльності В. Московченко дотримується саме таких принципів. Підсумовуючи сказане в інтерв'ю, В. Московченко зазначає, що йому імпонує «тип режисера, який усвідомлює свій обов'язок перед культурною ситуацією в регіоні і в місті». Щодо месіанства у професії режисера, то він зазначає: «Мене лякає режисер, який відчуває на собі месіянство. Мені здається, такі люди дуже небезпечні» (Московченко, 2006, с. 75).

Згадуючи етапи свого творчого шляху, В. Московченко визначає головну роль Луганського музично-драматичного театру. У цих спогадах помітна ще одна риса його творчої особистості - ніколи не починати свою діяльність з революційних рухів. Вони руйнують не тільки окремі творчі особистості, а й театр загалом. у таких висновках він спирається на власний досвід роботи в Маріупольському театрі, де творча «колотнеча» у колективі призвела до негативних наслідків.

3 теплом В. Московченко згадує колишнього керівника української трупи Ворошиловградського музично-драматичного театру М. Голубовича: «Він передав керівництво творчою частиною мені, а сам залишився актором, з власною енергійною дуже яскравою позицією» (Московченко, 2006, с. 76). Під його рукою, підтримкою чи, навпаки, дуже прискіпливим поглядом починалася робота режисера в цьому театрі.

Велику увагу у своєму інтерв'ю В. Московченко приділяє аналізу українського театрального життя. Отримавши досвід під час стажування в провідних театрах Ленінграда і Москви, він наголошує на тому, що є прихильником «класичного» ставлення до театрального мистецтва як форми духовності, яка виховує та підіймає людину над буденними потребами. Утім український тогочасний театр демонстрував зворотне. До нього було ставлення, як до мистецтва другорядного і непотрібного. Режисер пригадує вистави, які він бачив. У них були відсутні елементи сучасної естетичної та художньої мови.

Ці враження спонукали В. Московченка почати реформи у Луганському театрі через упровадження засобів сучасної режисури, які мали позитивний відгук в акторському середовищі. Саме актори першими відчули внутрішню потребу в змінах, що спрощувало процес роботи над виставами. 
Bulletin of Kyiv National University of Culture and Arts

Series in Stage Art

Колектив палав бажанням працювати та виконувати нові завдання. Ускладнювало цей процес, як наголошує режисер, прагнення бути «трішечки К. Станіславським, трішечки В. Немировичем-Данченком, трішечки Лесем Курбасом».

Це своє "трішечки» В. Московченко пояснює своїм ставленням до класиків режисури. К. Станіславського він називає «великим методологічним вчителем», його режисерську школу вважає номером один, адже вона перешкоджає режисеру впадати в крайнощі.

Не з меншою повагою говорить і про Леся Курбаса, який для нього є «режисером із солідним театральним та інтелектуальним підґрунтям, індивідуальним підходом», чого він не бачить в інших режисерів, навіть у славнозвісного Всеволода Меєрхольда.

В інтерв'ю В. Московченко не обминає питання про людські якості режисера. Він негативно оцінює представників цього фаху «... зубастих, крикливих, істерично галасливих». Ідеал для нього - головний режисер Жданівського (Маріупольського) театру О. Утєганов, який був «людиною толерантною, інтелігентною, демократичною».

Серед своїх сучасників В. Московченко з теплом згадує Анатолія Ефроса (1979), телевізійні та радіоспектаклі якого стали для майстра доброю школою; демократичність вистав М. Захарова (1987) та академічність Г. Товстоногова (1986) - це також той інструментарій, який використовує у своїй творчості митець.

Про естетичні смаки режисера свідчать його оцінки класичної та сучасної драматургії. Особливо підкреслює своє захоплення російською літературою, зокрема творами А. Чехова та І. Тургенєва. Він наголошує на необхідності сценічного відтворення цих творів мовою оригіналу. I для нього це є принциповим.

Аналізуючи сучасну драматургію, В. Московченко підкреслює, що вона за своїми художніми якостями не завжди сприяє розвитку режисерської творчості. Саме цим обумовлює своє звернення до В. Шекспіра. Його твори називає «вишуканою драматургією», що дає змогу шукати нові рішення та фарби, які їі, так би мовити, «дописують». На питання кореспондентки Світлани Максименко, чого саме режисеру бракує в Шекспірові, В. Московченко відповідає: «Він хоче сказати дуже багато про весь світ. Я не маю таких можливостей: акторських, технічних і ще інших. Я обираю одну тему. Скажімо, наш "Антоній і Клеопатра" [...] викликала зацікавлення своєю красою, поетичністю» (Московченко, 2006, с. 78).

В останній частині інтерв'ю В. Московченко говорить про режисерську мудрість, коли не виникає потреби в зайвих рухах, ає одне лише бажання зосередитися на солідній драматургії. Це дає змогу частково переформатувати діяльність театру та спланувати її як перебіг тематично визначених творчих сезонів. Як приклад він наводить сезон сучасної драматургії, завдяки якому публіка ознайомилася з творчістю американського драматурга Н. Саймона, п'єсами Т. Іващенко та А. Крима. Режисер прогнозує, що цікавими для луганців $є$ і наступні сезони, в яких представлено твори класичної драматургії, зокрема п'єси «Міщанин шляхтич» Мольєра, «Два веронці» В. Шекспіра.

Дуже важливий штрих до загального портрета режисера. Ці вистави призначені для молодого акторського складу театру, а також молодіжної глядацької аудиторії. 
Виховний потенціал твору - головний критерій, на який орієнтується В. Московченко у формуванні репертуару театру. Це стосується не тільки колективу, а й публіки. Саме з цією метою він звертається до творчості Г. КвіткиОснов'яненка (п'єси «Сватання на Гончарівці») та сучасних українських драматургів (наприклад, «Приборкання норовливого» Я. Стельмаха). Вистави, в яких режисер апелює до традицій комедії дель арте, поєднуючи їх з прийомами класичного театру. Як результат - спектаклі зі сучасною пластикою, музикою, потужною енергетикою. Саме ці якості сприяли перемогам колективу на фестивалях у Макіївці, Херсоні, Донецьку та зростанню театральних прихильників.

Актуальною $є$ і позиція В. Московченка щодо мовного складника вистави у проєкціях взаємозв'язків театр - публіка. Він наголошує:

«У таких містах, як Луганськ, Донецьк, де домінує російськомовне населення, режисер має витрачати великі зусилля на творення яскравих, театрально-агресивних спектаклів. Якщо позбутися цієї зовнішньої активности, акцентувати на вербальній сфері, глядацька увага послаблюється, виникає певна агресія залу. Я свого часу був свідком (у нас тоді в одному приміщенні працювало дві трупи: російська та українська): коли відкривалась куртина, звучали перші українські фрази, публіка починала поводитись так, ніби дві години свого часу та гроші вона викинула на смітник. Для мене $є$ важливим позбутись такої реакції, розчарованих облич». (Московченко, 2006, с. 78)

Тактику, яку використовує В. Московченко у формуванні репертуару, режисер виправдовує загальними змінами, що відбулися в державі, які сприяли зростанню інтересу до української культури. Про це свідчить і те, що навіть російськомовна публіка віддає перевагу українському театру, її затягує в ньому дія і театральна видовищність.

Заслуга митця полягає в тому, що Луганський театр утвердився як український. Позитивною тенденцією, на думку В. Московченка, $є$ те, що мова театру українська, це дає змогу активніше брати участь у театральних фестивалях.

Така установка в загальній політиці театру посилює в засобах режисури елементи універсальності, метафоричності, театральності.

Характеризуючи свою діяльність, режисер не обминає і самокритичних оцінок, які спонукають його більш глибоко занурюватися в авторські тексти та шукати в них той життєвий сенс, який є актуальним для сьогодення. Свій підхід у роботі над українською класикою, посилаючись на досвід постановок «Безталанної» Івана Тобілевича, «Свіччине весілля» Івана Кочерги, «Ніч під Івана Купала» Михайла Старицького та «Титарівна» Панаса Мирного, В. Московченко пояснює так: «Я зрозумів, що не зможу її ставити так, як написав автор. У таких випадках треба знайти зернятко, енергетичний центр української п'єси, і на ньому будувати виставу так, як ти її сьогодні розумієш, у сучасній театральній естетиці». У своїх постановках режисер пропонує нову лексику та театральну мову, позбувається зафіксованих і зазначених у тексті прийомів, наслідує не форму, а занурюється в суть твору. Нове режисерське прочитання класичних творів не завжди однозначно приймає художня рада театру, глядач і критика. «Скажімо, - 
згадує В. Московченко, - мені закидали, що у масових сценах жінки без взуття, босі. Я вичитав, бачив у знайдених іконографічних матеріялах: в українських селах жінки ходили босі, а звідси й інша їхня пластика, рухи. На сцені це викликало здивування, всі звикли до героїнь у черевичках, до підборів, відповідної ходи». Також не одностайно сприйняли режисерський прийом у «Свіччиному весіллі», де головна героїня не розмовляла, а лише співала. Але у фіналі, після сцени зґвалтування, її голос ставав спаленим, вона вже не могла співати, лише виголошуючи останні кілька фраз, вона помирає (Московченко, 2006, с. 79).

Слід наголосити також на тому, що ці принципи в його творчості не є сталими. У кожній п'єсі українських авторів він шукає такі виразні засоби, які б найбільш повно розкривали внутрішній зміст закладених у них сюжетних ліній, образних протистоянь або доповнень, конфліктів та їх розв'язання, які здатні, на думку режисера, збагатити їхнє сценічне прочитання. Тому всі вистави майстра не схожі одна на одну, навіть якщо за сюжетами мають схожість стильових ознак. Про це говорить і сам В. Московченко, наводячи приклад постановки «Титарівна» за твором М. Кропивницького, де у втіленні фабули сюжету за допомогою режисерських засобів здійснено перехід від бурлеску до яскравої поетики, наче, за словами майстра, усе відбувається «не на землі, а в інших світах». Інше режисерське рішення вбачаємо у виставі «Ніч під Івана Купала» за твором М. Старицького. Тут купальська ситуація набуває особливого значення та сприймається як таємниче, містичне, загадкове кохання. Цікавий театральний досвід здобуто завдяки постановці вистави «Ой, не ходи, Грицю», яку називаємо «Зимове кохання». Після літньої загадкової вистави, де «грала» жива вода, в яку кидали Купала, згадали й про інше кохання, замерзле від холоду. Українська тема у творчості В. Московченка не обмежується жанрово-побутовою тематикою, притаманною традиційному національному театру. Сповідуючи думку про те, що театр насамперед виконує найважливіші соціальні функції, зокрема об'єднує суспільство за національними інтересами та виховує толерантність до іншомовних культурних традицій, режисер боляче переживає політично нав'язаний поділ України на Схід і Захід, українськомовних та російськомовних. В. Московченко наголошує:

«Я стовідсотковий централіст. Свого часу вивчав політичну ситуацію Франції і знаю, що країна була врятована завдяки міцній централізації. Нас можна поєднати лише духовно. Коли наш театр приїздив до Києва, ми зустрічали там пихатих дядьків, які відверто говорили, що у нас, у Луганську, немає України. Ця пихатість мене дуже ображала. І давала мені енергію працювати саме тут. Я хочу довести, що ми така ж справжня, чиста, нормальна Україна, як і та, так звана найукраїнніша Україна тих дядьків. Оце і є моєю позицією». (Московченко, 2006, с. 80)

За таких умов функціонування театру вимагає певної визначеності, яка для В. Московченка полягає в моделі репертуарного театру. Ця модель, на його думку, дає змогу зробити театральне життя динамічнішим, коли глядацький зал відчуває себе його учасником і водночас дійовою особою, здатною змінити на позитив своє та суспільне життя. Репертуарний театр дасть змогу охоплюва- 
ти широкі верстви населення й об'єднувати їх в єдиний людський організм як уособлення вищої гармонії і духовності. Це змушує бути в режисурі не тільки революціонером, а й консерватором, допомагає митцю трансформувати театр як уособлення вселюдської єдності у форму зв'язку між минулим і нинішнім із закладеним у цю форму філософським та інтелектуальним змістом.

Визначною подією 2008 року стала постановка епічної драми «Тарас Бульба» сучасного драматурга Л. Томи. Творча група на чолі з В. Московченком і майже весь акторський склад театру створили по-справжньому високопрофесійну, масову, яскраву, героїко-патріотичну виставу, яка яскраво заявила про себе на фестивалях «В гостях у Гоголя» (м. Полтава, 2009 р.) і «Мельпомена Таврії» (м. Херсон, 2009 р.).

Про незмінність позицій режисера, продекларованих у вищезгаданому інтерв'ю, яскраво свідчать постановки 2016-2018 років: французька комедія «Обережно - жінки!» А. Курейчика, трагіфарс «Маклена Ґраса» М. Куліша (представляв театр на Міжнародному фестивалі «Мельпомена Таврії», м. Херсон, 2016 р.), музична комедія «Потрібен брехун!» Д. Псафаса, комедія «Звідки беруться діти» А. Крима, комічне фентезі «Станція» О. Вітера, іронічна притча «Лавина» Т. Джюдженоглу, комедії «Веселий дух» Н. Кауарда та «Мірандоліна» К. Гольдоні.

Новою роботою В. Московченка в жовтні 2017 р. став реп-бурлеск «Конотопська відьма» за повістю Г. Квітки-Основ'яненка, в якому художні пошуки режисера поєдналися з морем акторської щирості та мистецької зухвалості, безліччю пісень, танців і видовищної пластики. Глядачі ж мали святковий, піднесений настрій завдяки зустрічі майже з усім творчим складом театру, а також вибуховий енергетичний коктейль з мальовничого гумору й запальних веселощів від постановчої групи.

Виступивши автором інсценізації твору, режисер сміливо занурюється до сучасного трактування драматургічних колізій, які злободенністю, а іноді й вічною проблематикою знаходять гарячий відгук в аудиторії.

Перегук з реаліями сьогодення додають тексти віршів у реповому виконанні. Зухвала молодь весело коментує події та дає їм оцінку. Містичне звучання сучасних інструментальних композицій і звукових ефектів органічно переплітається з автентичним співом, який актори відтворюють а капела або акомпануючи собі на бубнах, тулумбасі, порожніх пляшках тощо. Вистава, поєднуючи жанр сатиричного бурлеску з чудернацькими, комедійними ситуаціями, танцями, піснями, бійками, інтермедіями, дає публіці привід поміркувати над тим, скільки літ пройшло, однак нічого не змінилося. На сцені яскраво взаємодіють світлові ефекти, сучасне музичне оформлення, багатофункціональна стилізація сценографії та костюмів, динамічна пластика. Усе це робить повну гумору та дотепних ситуацій класику живою для будь-якого покоління.

Наукова новизна дослідження полягає в тому, що вперше творчий шлях В. Московченка та його діяльність в Луганському обласному академічному музично-драматичному театрі розглянуто як одну з вагомих сторінок українського театрального життя. 


\section{Висновки}

Отже, можна зробити висновок, що кожна робота В. Московченка має свою театральну форму, свій хід режисерської думки, яка не тільки тісно пов'язана з першоджерелом, авторською п'єсою, а й надає йому інтерпретаційних ознак паралельного художнього світу, відтвореного в гармонії всіх складників театральної вистави. Дослідження засвідчило наявність у майстра індивідуального стилю та мовної стилістики як системи, що впливає на сприйняття сценічних образів як самостійних режисерських персонажів, які проводять глядача через усі сценічні колізії, закладені режисерським задумом.

\section{СПИСОК ПОСИЛАНЬ}

Василько, В.С., 1967. Фрагменти режисури. Київ: Мистецтво.

Василько, В.С., 1984. Театру віддане життя. Київ: Мистецтво.

Голубцова, Л.Ф., 2001. Сучасна режисерська діяльність як складова частина культуротворчого процесу. Автореферат дисертації кандидата мистецтва. Державна академія керівних кадрів культури і мистецтв.

Данченко, С.В., 1999. Бесіди про театр. Київ.

Захава, Б.Е., 1978. Мастерство актера и режиссера. Москва: Просвещение.

Захаров, М.А., 1987. Контакты на разных уровнях. Москва: Искусство.

Ільків, В., 2011. Бути чи не бути молодій українській режисурі в XXI столітті? Кіно-Театр, [online] 3. Доступно: <http://www.ktm.ukma.kiev.ua/show_content.php?id=1149> [Дата звернення 20 січня 2020].

Корниенко, Н., 2005. Режиссерское искусство Леся Курбаса. Реконструкция (1887-1937). Киев: Государственный центр театрального искусства имени Леся Курбаса.

Курбас, Л., 2001. Філософія театру. Київ: Видавництво Соломії Павличко "Основи".

Маркевич, А., 2005. Август, война, театр. Жизнь Луганска, 42, с.19.

Митницький, Е. та Олтаржевська, Л., 2013. Едуард Митницький: Квола мораль веде до шахрайства у професії. Україна молода, 9 квітня.

Мірошниченко, Н., 2009. Сучасна українська драматургія: деструкція міфів та пошук нових територій. Дніпро, 1, с.116-119.

Московченко, В., 2006. Сувора професія - режисер... Розмовляла С. Максименко. Просценіум, 2/3 (15/16), с.75-80.

Неллі, В.О., 1977. Про режисуру. Київ: Мистецтво.

Підлужна, А., 2018. Підступність і кохання. День, [online] 207. Доступно: <https:// day.kyiv.ua/uk/article/kultura/pidstupnist-i-kohannya-0> [Дата звернення 11 лютого 2020].

Рєзнікович, М. та Олтаржевська, Л., 2013. Генеральний директор - художній керівник Національного театру імені Лесі Українки Михайло Рєзнікович: «Режисер - це професія, яка змушує говорити лише неприємності». Урядовий кур'єр, 27 квітня.

Терещенко, М.С., 1974. Крізь лет часу: театральні спогади. Київ: Мистецтво.

Товстоногов, Г.А., 1962. Современность в современном театре. Беседы о режиссуре. Москва: Искусство. 
Товстоногов, Г.А., 1986. О профессии режиссера. Москва: ВТО.

Эфрос, А.В., 1979. Профессия: режиссер. Москва: Искусство.

\section{REFERENCES}

Danchenko, S.V., 1999. Besidy pro teatr [Conversations about theater]. Kyiv.

Efros, A.V., 1979. Professiia: rezhisser [Profession: Director rector]. Moscow: Iskusstvo.

Holubtsova, L.F., 2001. Suchasna rezhyserska diialnist yak skladova chastyna kulturotvorchoho protsesu [Contemporary directorial activity as an integral part of the cultural process]. Abstract of PhD. State Academy of Management Personnel of Culture and Arts.

Ilkiv, V., 2011. Buty chy ne buty molodii ukrainskii rezhysuri v XXI stolitti? [To be or not to be a young Ukrainian director in the XXI century?]. Kino-Teatr, [online] 3. Available at: <http://www. ktm.ukma.kiev.ua/show_content.php?id=1149> [Accessed 20 January 2020].

Kornienko, N., 2005. Rezhisserskoe iskusstvo Lesia Kurbasa. Rekonstruktciia (1887-1937) [Director art of Les Kurbas. Reconstruction (1887-1937)]. Kyiv: Gosudarstvennyi tcentr teatralnogo iskusstva imeni Lesia Kurbasa.

Kurbas, L., 2001. Filosofiia teatru [Theater philosophy]. Kyiv: Vydavnytstvo Solomii Pavlychko "Osnovy".

Markevich, A., 2005. Avgust, voina, teatr [August, war, theater]. Zhizn Luganska, 42, p.19.

Miroshnychenko, N., 2009. Suchasna ukrainska dramaturhiia: destruktsiia mifiv ta poshuk novykh terytorii [Contemporary Ukrainian dramaturgy: the destruction of myths and the search for new territories]. Dnipro, 1, pp.116-119.

Moskovchenko, V., 2006. Suvora profesiia - rezhyser... [Strict profession - director...] S. Maksymenko spoke. Prostsenium, 2/3 (15/16), pp.75-80.

Mytnytskyi, E. and Oltarzhevska, L., 2013. Eduard Mytnytskyi: Kvola moral vede do shakhraistva u profesii [Eduard Mitnitsky: Bad morality leads to fraud in the profession]. Ukraina moloda, 9 April.

Nelli, V.O., 1977. Pro rezhysuru [On directing]. Kyiv: Mystetstvo.

Pidluzhna, A., 2018. Pidstupnist i kokhannia [Craftiness and love]. Den, [online] 207. Available at: <https://day.kyiv.ua/uk/article/kultura/pidstupnist-i-kohannya-0> [Accessed 11 February 2020]. Rieznikovych, M. and Oltarzhevska, L., 2013. Heneralnyi dyrektor - khudozhnii kerivnyk Natsionalnoho teatru imeni Lesi Ukrainky Mykhailo Rieznikovych: "Rezhyser - tse profesiia, yaka zmushuie hovoryty lyshe nepryiemnosti" [Mykhaylo Reznikovich, General Director Artistic Director of the Lesya Ukrainka National Theater: "Directing is a profession that only makes trouble"]. Uriadovyi kurier, 27 April.

Tereshchenko, M.S., 1974. Kriz let chasu: teatralni spohady [Through the years of time: theatrical memories]. Kyiv: Mystetstvo.

Tovstonogov, G.A., 1962. Sovremennost v sovremennom teatre. Besedy o rezhissure [Modernity in a modern theater. Conversations about directing]. Moscow: Iskusstvo.

Tovstonogov, G.A., 1986. O professii rezhissera [About the profession of director]. Moscow: VTO. Vasylko, V.S., 1967. Frahmenty rezhysury [Fragments of directing]. Kyiv: Mystetstvo.

Vasylko, V.S., 1984. Teatru viddane zhyttia [The theater is dedicated to life]. Kyiv: Mystetstvo. Zakharov, M.A., 1987. Kontakty na raznykh urovniakh [Contacts at different levels]. Moscow: Iskusstvo. 


\title{
СПЕЦИФИКА РЕЖИССЕРСКОГО ТВОРЧЕСТВА ВЛАДИМИРА МОСКОВЧЕНКО В ДИНАМИКЕ РАЗВИТИЯ ТЕАТРАЛЬНОЙ КУЛЬТУРЫ ЛУГАНСКОГО РЕГИОНА
}

\author{
Татьяна Нечаенко ${ }^{1 a}$, Сергей Плуталов ${ }^{2 b}$, Алена Дорофеева ${ }^{3 c}$ \\ ${ }^{1}$ специалист, доцент; e-mail: nechaenko.t@gmail.com; ORCID: 0000-0002-8329-2517 \\ ${ }^{2}$ специалист; e-mail: si.plutalovv@gmail.com; ORCID: 0000-0001-9155-5324 \\ ${ }^{3}$ магистр; e-mail: alena.dorofeeva@ukr.net; ORCID: 0000-0001-6488-3031 \\ а Киевский национальный университет культуры и искусств, Киев, Украина \\ ' Луганская государственная академия культуры и искусств, Киев, Украина \\ с Луганский областной академический украинский музыкально-драматический театр, Киев, Украина
}

\section{Аннотация}

Цель исследования заключается в историко-аналитическом и искусствоведческом анализе современных режиссерских практик на сцене Луганского областного академического музыкально-драматического театра на примере творчества одного из ведущих его представителей В. Московченко. Методология исследования базируется на комплексном научном подходе и синтезе следующих методов: историко-аналитического - в исследовании режиссерского искусства В. Московченко в контексте театральной культуры Украины в целом; биографического как средства определения этапов творческого становления художника; теоретического - для научного обобщения и систематизации фактологического материала. Научная новизна исследования заключается в том, что впервые творческий путь В. Московченко и его деятельность в Луганском областном академическом музыкальнодраматическом театре рассмотрена как одна из значимых страниц украинской театральной жизни. Выводы. Каждая работа В. Московченко имеет свою театральную форму, свой ход режиссерской мысли, не только тесно связанной с первоисточником, авторской пьесой, но и придающей ему интерпретационных признаков параллельного художественного мира, воссозданного в гармонии всех составляющих театрального представления. Именно это говорит о наличии в мастера индивидуального стиля и языковой стилистики как системы, влияющей на восприятие сценических образов в качестве самостоятельных режиссерских персонажей, проводящих зрителя всеми путями сценических коллизий, заложенных режиссерским замыслом. На сцене Луганского областного академического украинского музыкально-драматического театра как духовного центра культурной жизни региона продемонстрирована широкая палитра театральных красок и режиссерских находок В творчестве В. Московченко, направленных на сочетание ведущих тенденций развития театрального искусства с опытом корифеев отечественной сцены.

Ключевые слова: Луганский областной академический украинский музыкальнодраматический театр; театральная режиссура XX века; В. Московченко 


\title{
SPECIFICITY OF DIRECTOR'S CREATIVITY OF VOLODYMIR MOSKOVCHENKO IN THE DYNAMICS OF THE THEATER CULTURE DEVELOPMENT IN LUHANSK REGION
}

\author{
Tetiana Nechaenko ${ }^{1 a}$, Serhii Plutalov ${ }^{2 b}$, Alyona Dorofeeva ${ }^{3 c}$ \\ ${ }^{1}$ specialist, associate professor; e-mail: nechaenko.t@gmail.com; ORCID: 0000-0002-8329-2517 \\ ${ }^{2}$ specialist; e-mail: si.plutalovv@gmail.com; ORCID: 0000-0001-9155-5324 \\ ${ }^{3}$ Master; e-mail: alena.dorofeeva@ukr.net; ORCID: 0000-0001-6488-3031 \\ ${ }^{a}$ Kyiv National University of Culture and Arts, Kyiv, Ukraine \\ ${ }^{b}$ Luhansk State Academy of Culture and Arts, Kyiv, Ukraine \\ c Luhansk Regional Academic Ukrainian Music and Drama Theater, Kyiv, Ukraine
}

\begin{abstract}
The purpose of the article is to analyze the historical-analytical and art-scientific analysis of the contemporary directing practices formation of the Lugansk Regional Academic Music and Drama Theater on the example of creativity of one of its leading representatives, Vladimir Yurievich Moskovchenko. The methodology of the research is based on a comprehensive scientific approach and synthesis of the following methods: historical and analytical in the study of the directing art of V.Yu. Moskovchenko in the context of the theater culture in Ukraine as a whole; "Biographical" as a means of determining the stages of creative becoming of the artist; theoretical is for scientific generalization and systematization of factual material. The scientific novelty of the research results is that: for the first time, the creative path of V.Yu. Moskovchenko and his activities in the Luhansk Regional Academic Music and Drama Theater have been considered as one of the important pages of Ukrainian theatrical life. Conclusions. Each work of V. Moskovchenko has its theatrical form, its own course of directorial thought, which is not only closely connected with the primary source, the author's play, but also gives him interpretive features of the parallel art world, reproduced in harmony of all components of the theatrical performance. This is what allows us to claim that the master of individual style and linguistic stylistics as a system that influences the perception of stage images as independent "directing characters", which guide the viewer in all the ways of stage conflicts set by the director's plan. Lugansk Regional Academic Ukrainian Music and Drama Theater, as the spiritual center of the cultural life of the region, demonstrates in the works of V.Yu. Moskovchenko a wide palette of theatrical colors and directorial findings aimed at combining the leading tendencies of the theatrical art development with the domestic scene experience.
\end{abstract}

Keywords: Luhansk Regional Academic Ukrainian Music and Drama Theater; Theater Directing of the XX Century; V. Moskovchenko 